Summer 2011

\title{
That's the Beauty of It, Or, Why John Ashbery is Not a Painter
}

Clark Lunberry

University of North Florida, clark.lunberry@unf.edu

Follow this and additional works at: https://digitalcommons.unf.edu/aeng_facpub

Part of the Painting Commons, and the Poetry Commons

\section{Recommended Citation}

Lunberry, Clark, "That's the Beauty of It, Or, Why John Ashbery is Not a Painter" (2011). English Faculty Publications. 8.

https://digitalcommons.unf.edu/aeng_facpub/8

This Article is brought to you for free and open access by the Department of English at UNF Digital Commons. It has been accepted for inclusion in English Faculty Publications by an authorized administrator of UNF Digital Commons. For more information, please contact Digital Projects.

(C) Summer 2011 All Rights Reserved

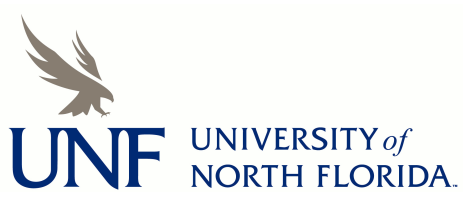




\title{
That's the Beauty of It, Or, Why John Ashbery is Not a Painter
}

\author{
Clark D. Lunberry \\ University of North Florida
}

The poet John Ashbery lived in Paris from roughly 1955 to 1965. It was during this period that Ashbery began writing art reviews, often examining the work of various Americans also living in Paris at this time. Among the many painters Ashbery was to review and publish about, one was the Chicago-born, Paris-based abstract expressionist Joan Mitchell and an exhibition of hers at a Paris gallery in 1964. In this essay ${ }^{1}$ I examine the early, more "abstract" poetry that Ashbery was developing during this period, thinking about it alongside the paintings of Mitchell (and, in particular, his writings about them). My contention is that Ashbery was in many ways emboldened by Mitchell's complex engagements with representation and abstraction, especially as they relate to the landscape. Ashbery was, through his close examination of such work, moved towards ever greater poetic and linguistic experimentations of his own.

Keywords: John Ashbery / Joan Mitchell / abstraction / poetry / painting

In the beginning was the word. Then they put two words together, then they made a sentence, then they made a paragraph and they forgot the word.

-Gertrude Stein

\section{GIROLATA}

Picturing a poet as a painter, a painter as a poet, can be of some real value in reading a poem and in looking at a painting. After all, the one has often acknowledged, or even embraced, the other as an influence, an inspiration, a guide of sorts through the landscape of language, the language of color and form. To see words where there is paint, paint where there are words, might thus offer a kind of frame or focus, a defining image, a clarifying correspondence between the one and the other, the other and the one. Of course, such a commingling of figures might also cause conflict, making indistinct the otherwise obvious, with the pictured poet or painter dissolved in the blur of boundaries, the referential dilutions. However, 
as Wittgenstein explicitly asked (and then implicitly answered) of an imagined photograph of a person, "Is an indistinct photograph a picture of a person at all? Is it even always an advantage to replace an indistinct picture by a sharp one? Isn't the indistinct one often exactly what we need?" (29).

Such pictorial in-distinctions between a poet and a painter, between poetry and painting, would seem to have offered the poet John Ashbery "exactly" what he needed during his own extended stay in Paris, straddling those two vital, postwar decades of the 1950s and '60s. Not that Ashbery was painting at the time, but neither was he writing poems with titles like his friend Frank O'Hara's "Why I am not a Painter." Still, in Paris, he was certainly getting to know and writing about a number of painters who were then living in the city, many of them Americans, "professional exiles" (Moorings 217) like himself, who were continuing the long and rich tradition of finding in Paris, not their country, but (as Gertrude Stein famously stated) their "hometown" ("An American and France" 238). ${ }^{2}$ Among them was the painter Joan Mitchell, of whose 1964 exhibition Ashbery was to write a review that was then published in ArtNerws the following year.

Ashbery has openly acknowledged that "Poets when they write about other artists always tend to write about themselves" (Reported 106). Not surprisingly, then, in reading his review of Mitchell's Paris exhibition, there is the strong sense that, as in so many of his other reviews of that time, Ashbery is writing about Mitchell's new paintings as a means, in part, of thinking and writing about his own poetry. Or rather, at one remove from his primary preoccupation as a poet, by looking at the medium of paint as a means of representation, and, in Mitchell's case, as a means of representing the landscape (what Ashbery describes as the painter's "unhurried meditation on bits of landscape and air" [Reported 99]), the poet is perhaps recognizing a way to understand further aspects of his own concurrent engagements with the medium of language and its own capacity (or incapacity) to represent something of those "bits of landscape and air" around him. But what was it that Ashbery may have been admiring in Mitchell's paintings, offering a new kind of license for the poet's own looking and writing? What might he have been seeing on the painter's vivid and lyrical surfaces, amidst those "bits" of calligraphic color and curve that would have suggested parallel lessons in language, perhaps even emboldening and empowering him towards still greater representational liberties through these lessons?

A couple of years before his review of Mitchell's exhibition, in a brief statement requested by the publisher about his 1962 Paris-based book The Tennis Court Oath, Ashbery made reference to painting's potential as a device for "abstract" representation, explaining, as if offering an oath of his own, that:

I attempt to use words abstractly, as an abstract painter would use paint. . . My aim is to give the meaning free play and the fullest possible range. As with the abstract painters, my abstraction is an attempt to get a greater, more complete kind of realism. (Jacket Copy) 
There is, at first glance, a more than minor, if intended, paradox or provocation in this comment where Ashbery is playing off the conventional divide (especially pronounced in that post-war period) between abstraction and realism, representation and non-representation. However, Ashbery here suggests a bridge of sorts between these two often imagined irreconcilable pictorial poles and an almost dialectical synthesis that resolves them into "a greater, more complete kind of realism." With paint or a poem, abstraction is thus being reconceived as not actually abstract at all, but instead as offering a more accurate and realistic means of representing something of the dense and simultaneous multiplicities of the real, of realizing those "bits of landscape and air" that both the poet and the painter see swirling unsteadily before them, feel floating all around.

Ashbery's uncharacteristically frank comment about his book-one that he later claimed to regret, saying that it has "haunted" him ever since (Lehman $99)^{3}$ - nonetheless seems quite helpful in conceptually positioning us as readers, both then and now, as if physically positioning us before a painting upon a wall, to better see something of what the poet's words are doing, or rather what those words are "attempt[ing]" to do (as Ashbery qualifyingly states twice). For Ashbery is encouraging us, as he appears at this early stage of his writing to have been equally encouraging himself, to wonder if words could function much like paint, the pen like a brush, the paper like canvas, with the subsequent act of reading approached as an act of linguistically charged looking; the poet's applied language is stretched and strained, pushed and pulled towards its own vibrantly infused materiality, into what Ashbery described, via the composer John Cage, as "isolated, autonomous tone-clusters" ("Introduction" ix). It must have seemed to Ashbery then, as it seems to me now, years later, a more than worthy effort to "attempt" such poetic parallels with the painterly (even if such an endeavor is finally to fail), the written or typedout words, like strokes or "clusters" of thick paint upon a canvas, one alongside the other, alongside the other, "giving meaning," as Ashbery ambitiously described it, "free play and the fullest possible range."

To see how such "meaning" through "abstraction" is actually achieved —or attempted-how Ashbery might in fact have "use[d] words abstractly, as an abstract painter would use paint," let's set the stage for such a reading by looking further at the poet's 1965 review of Joan Mitchell's "abstract" paintings of that period. Or are they abstract? And if so, how much so? For these are the kinds of concerns that dominate Ashbery's article, as he asks at one point, after detailing the manner in which Mitchell's paintings so often "suggest a landscape," "What then is the difference between, say, Joan Mitchell's kind of painting and a very loose kind of landscape painting?" (Reported 100). Looking ahead, we might (and we will) ask much the same about some of Ashbery's own more "abstract" poetry of that period and in particular his now legendary, or notorious, "Leaving the Atocha Station": what then is the difference between, say, Ashbery's kind of poetry and a very loose kind of landscape poem?

Ashbery directs his "loose ... landscape" concerns most fully to Mitchell's large triptych, Girolata [Figure 1] (named after a specific site in Corsica but, 

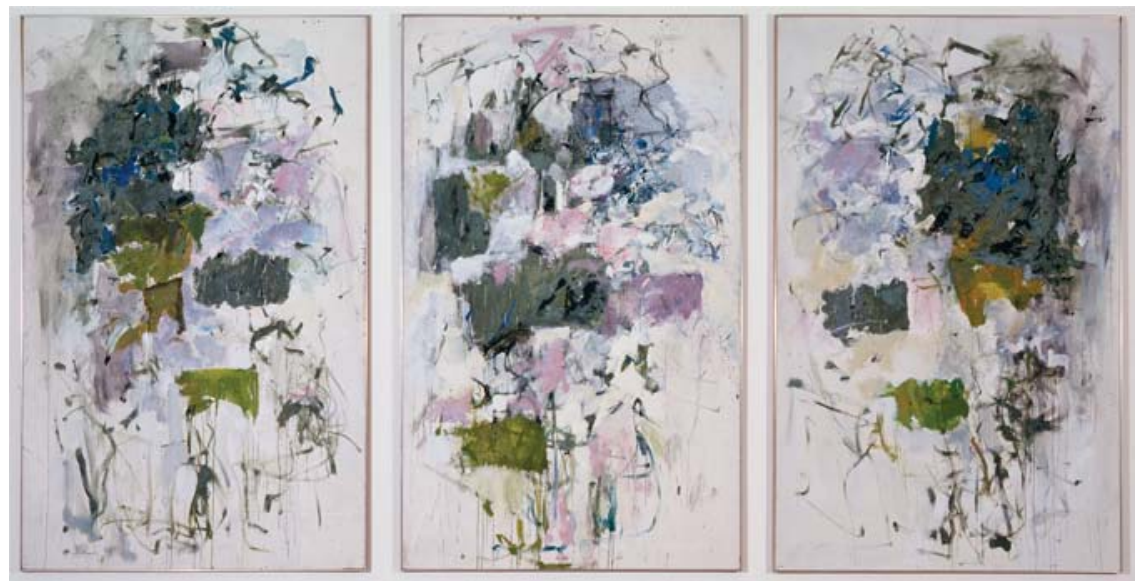

Figure 1. Girolata, Joan Mitchell (1964) oil on canvas. Hirshhorn Museum and Sculpture Garden, Smithsonian Institution, Gift of Joseph H. Hirshhorn, 1966. Photography by Lee Stalsworth. Reprinted with permission from the Smithsonian Institution, Washington, DC.

as Ashbery clarifies, only "after the picture was painted"), indicating that it "does look very much like a fairly literal impression of the face of a cliff pocked with crevices and littered here and there with vines. Even the colors," Ashbery continues, "are not too far from what they would be in an explicit representation of such a scene." With the apparent uncertainty about the painting's representational or non-representational status, Ashbery then concludes with a pointed question that, by substituting the word painting for poetry, could again be asked loosely of himself, for instance, leaving the Atocha Station, "Is this then figurative painting, and if so, what is the meaning of the term abstract ... ?" (Reported 100).

Ashbery goes on to answer his own question, or suggest an answer, about the apparently blurred boundary between the figurative and the abstract by splitting the difference between them and essentially embracing these indistinct distinctions (which, after all, might be, via Wittgenstein, "exactly what we need"), while indicating that "one's feelings about nature are," as Ashbery somewhat abstractly describes them, "at different removes from it" (Reported 101).

In time, in place, in memory and awareness, "one's feelings" are thus removed from the thing itself, from "it," from "nature." While for the painter (or the poet) what remains is what remains of what has been removed - what Ashbery characterizes as "reflections" of the sight seen, the feelings felt. These reflections are not representable memories exactly, but reflections of memories, or rather, reflections off memories, what Mitchell describes elsewhere as the "memory of a feeling" (Bernstock 175). For such "feelings," once had, are refracted now (like a glint of light) from an ever-receding surface, of a specific scene that one is now leaving - like a train station - "remove[d] from it," but with those abstracted "feelings" of having once been there. 
Reminiscent of a Proustian memory involuntarily received, such painted (or poetic) "reflections" of "bits of landscape and air" will therefore inevitably, by their very nature, waver and fragment in their deferred transference from sight to site, from seen to scene, from then to now, between the recognizable suggestion of a once-material moment ("the precise look of the creek, or cliff," Ashbery writes of Girolata) and its subsequently material manifestation in paint (or words) as "legible landscape." Indeed, it is this difficult dynamic, what Ashbery calls the "antagonisms and sparrings" between those glimpses of recognition and the very substance of paint, "the caked or viscous pigment" (Reported 101), he writes, that are thus reflected within the very in-distinctions of the represented scene, shifting unsteadily, flickeringly, and yet perhaps "exactly what we need" for the reflected feeling to be felt at all. At one remove from "it," the scene is then seen as seeming of something, resembling it (as if from a distance, in time, in space), but with the seams of its own semblance now exposed clearly and deliberately as real paint on a flat canvas, or actual ink on a thin piece of paper.

Elsewhere in his review, Ashbery quotes Mitchell as she describes her desire to "remember" with paint, to re-feel the abstracted reflections of a place, a time, a tree. She speaks of a specific scene recalled, a particular detail within it, "I'm trying to remember what I felt about a certain cypress tree and I feel if I remember it, it will last me quite a long time" (Reported 100). However, as with Marcel dipping and re-dipping the madeleine into his cup of tea, seeking each time a more certain sensation, such remembrance cannot be voluntarily enacted. One cannot, in a sense, try to remember (anymore than one can try to forget). Still, if now applying Ashbery's description of the painted recollection of a scene, of Mitchell's "certain cypress tree," a reflection of that scene "rather than the memory it suggests" might nonetheless be voluntarily made in order to then involuntarily reflect that remembrance, offering a viewer or reader a refracted access, one that is indeed "remove[d]" from the immediate sight but replaced by the immediately mediated sensation of it. The scene, as such - what was once there but is no longer - is not then seen at all, while "bits" of it have instead been abstractly extracted from its own dense net of previously received sensation, from the sight of the now nonsite itself and toward what Ashbery earlier described as "a greater, more complete kind of realism."

Even Mitchell's acknowledgement that Girolata was given its title "after the picture was painted" would seem to distance further the painting from the place, the place from the painting. After all, might it be that the specific and locatable Corsican site of Girolata [Figure 2], and Mitchell's painting titled Girolata, were - out of sync with each other-aligning only loosely, and only later as a re-collected moment in time? The mountains' growing vines, the painting's paint, its cracks and crevices, the lines of oily light now hardened and dry - all of these forms and forces now gesture, the one to the other, as if across a rocky and vertiginous abyss. Mitchell's mountainous painting still stands, years later, as a kind of echoing after-effect of a receding event, as the materialized and memoried sensation of an expanding absence. 


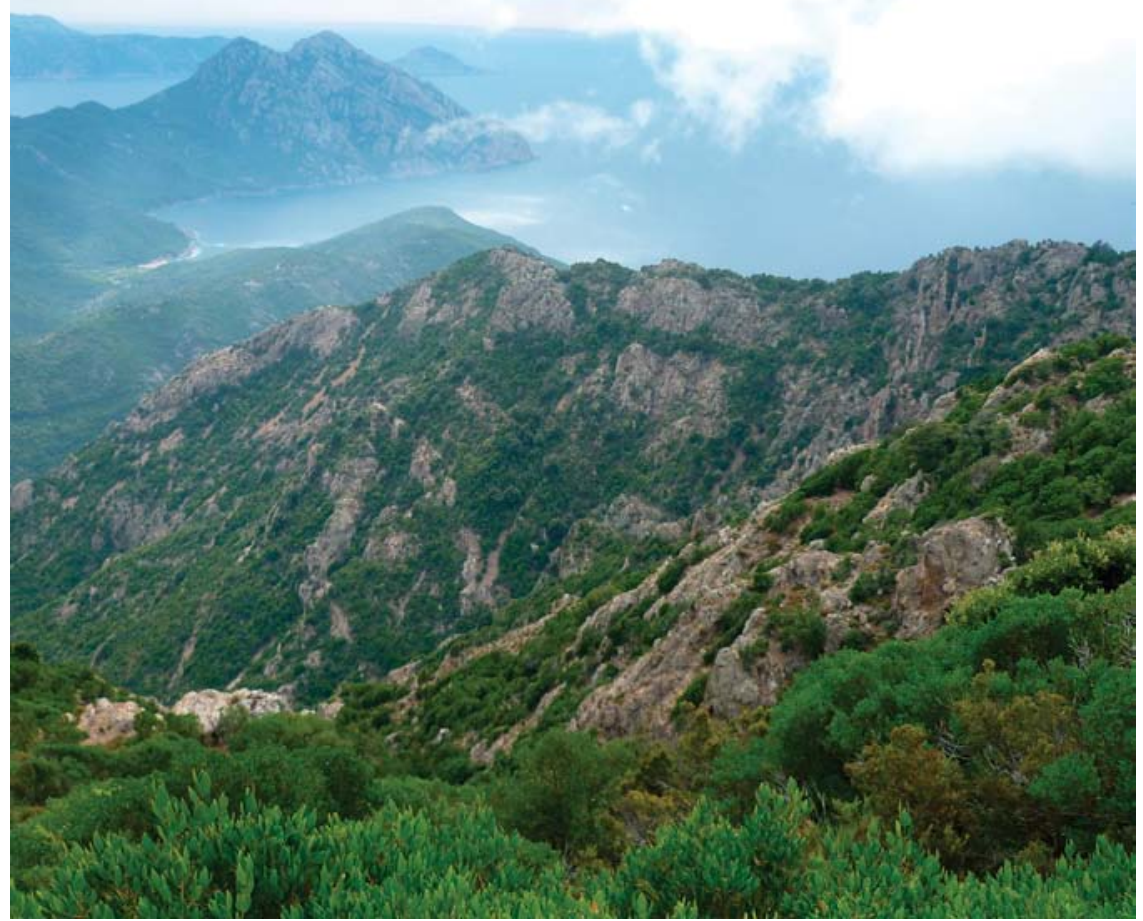

Figure 2. Girolata. Photograph by Wanda Sowry. Reprinted with permission from the artist.

The composer Morton Feldman (an acquaintance of both Ashbery's and Mitchell's), writing of his own musical compositions, paradoxically stated that "We do not hear what we hear ... only what we remember" (209). By extension, from Feldman's sound to Mitchell's sight (to Ashbery's parallel poetic perception), what the painter remembers, through paint, is what she has been unable to see, or unable to keep seeing, while offering now the painted reflection of her own remembrance, there, still, in "the caked or viscous pigment," and perhaps lasting her and us "quite a long time."

Years later and far removed from the specific scenes described above, in an interview with the French critic Yves Michaud, Mitchell described what she believed was the unique capacity of paint to stop or stall time, and thus to position the viewer to feel sensually a moment of such virtually sublime stasis:

Painting is a means of feeling "living" ... Painting is the only art form except still photography which is without time. Music takes time to listen to and ends, writing takes time and ends, movies end, ideas and even sculpture take time. Painting does not. It never ends, it is the only thing that is both continuous and still. Then I can be very happy. It's a still place. It's like one word, one image. ... (Stiles and Selz 32)

Mitchell here insists that writing, like other art forms (except, arguably, painting and photography), "take[s] time" to be seen and engaged, as the language is laid 
out chronologically upon a page, like a lined landscape to be crossed. Yet curiously, in her description of painting, offering "a means of feeling 'living,", she nonetheless uses metaphorically the very substance of writing to shape and resolve the stilled "but continuous" place of painting into "one word, one image." Mitchell goes on to extend or clarify her linguistic metaphor even further, stating that "My painting is not an allegory or a story. It is more like a poem" (Stiles and Selz 33). Legibly then, but "without time," without story, that one word as one image is thus read instantly "like a poem," a one word poem, reflecting like a glint of light off the surface of "a certain cypress tree."

\section{ATOCHA STATION}

With these reflections of remembrance in mind, let's now reflect back on Ashbery's own admission that "Poets when they write about other artists always tend to write about themselves." While I, in writing about Ashbery writing about Mitchell, am - let's be clear-writing about Ashbery writing about Ashbery. (Or am I writing about myself?) Or am I writing about Ashbery's "Leaving the Atocha Station" and the reflected sensations of what might be read, as Ashbery had read Mitchell, as a "loose kind of landscape poem"? For that poem's sentenced progressions across the printed page, lining it like train tracks, are almost painterly in their legibility, "pulling us out of there experiencing it," as Ashbery leadingly writes at the very beginning of that poem.

But "experiencing" what? What is the "it" of that it, pronominally shifting into that which one is, apparently, being pulled out of? And also is something of this "it" evidence - if only in its reflected, refracted form — of that "greater, more complete kind of realism" that Ashbery had earlier said that he sought, but also said that he'd seen in Mitchell's "unhurried meditation on bits of landscape and air"?

In "Leaving the Atocha Station," we are, it seems, far removed from the "one word, one image" that Joan Mitchell affirmed of painting, that timeless "still place" that made her "very happy" and granted her, with its Stein-like flow of coupling gerunds, "a means of feeling 'living.” For, to read Ashbery's poem certainly "takes time," whether we like it or not, or whether it makes us "happy" or not, and for some, this particularly abstract poem has not made them happy, in part because of the very time that it takes to read it. True, at two pages, it's not much time, but enough time to feel that time has been taken from you, or worse, wasted wantonly - with what Harold Bloom dismissively characterized as its "calculated incoherence" (53). Still, even though Joan Mitchell disparaged the time needed to engage writing (while paradoxically comparing her paintings to "a poem," to "one word"), might Ashbery's actual poem, for all its wordiness and time-consuming qualities, be seen to reflect a parallel, if painterly, aspiration in poetry, one that is finally both "continuous and still" and offering also, abstractly, a realistic "means of feeling 'living"? Lastly, might Ashbery have even been partially prompted to such aspirations of felt immediacy, of such distilled 


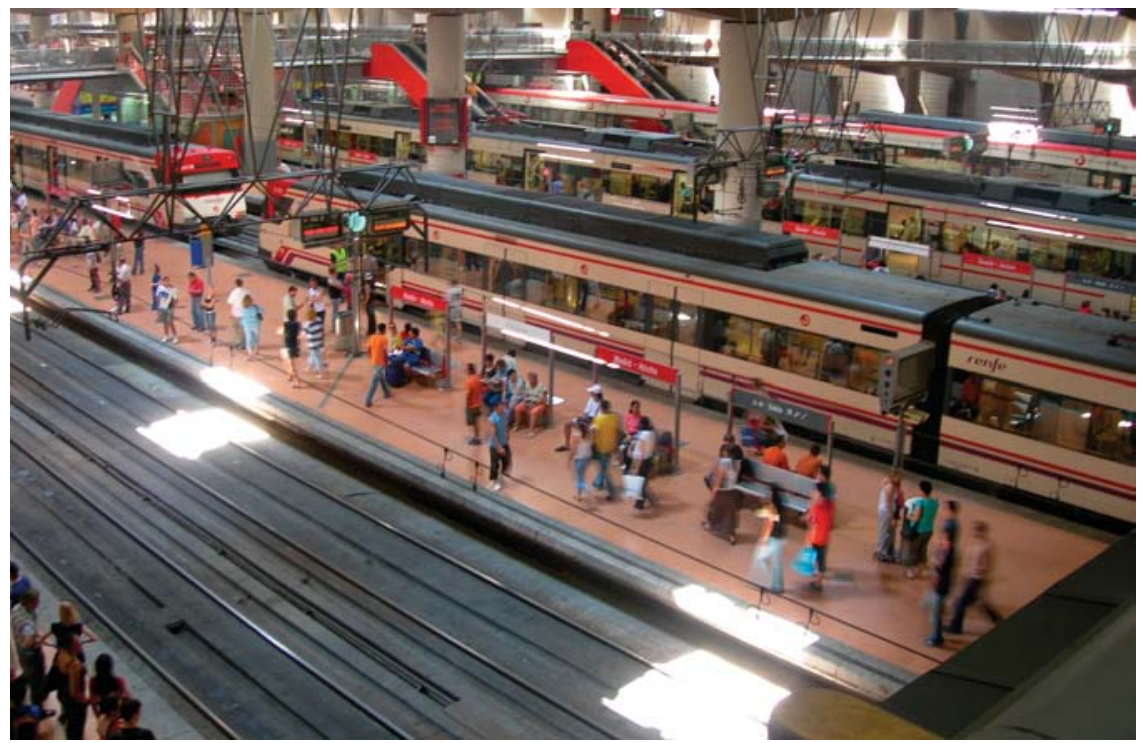

Figure 3. Atocha Station, Madrid, Spain. Photograph by Mike Chamberlain. Reprinted with permission from the artist.

stasis, by having examined closely those mediated immediacies reflected in or off of Mitchell's own paintings?

Like Mitchell's already discussed painting with the Corsican title Girolata, the title of Ashbery's "Leaving the Atocha Station" also names a particular place, in Madrid [Figure 3], which in the naming, offers a tentative setting for what follows, the centrally located Atocha Station. In Ashbery's case, though, his title presents a named location that we seem to be already "leaving," with the poem set in motion before it's even begun.

Or rather, might this initial "leaving" before beginning be something like that odd, illusory sensation of - while waiting to depart from a station - seeing from the window an adjacent train's motion and confusing it with one's own? The world slips away, the ground beneath us moving, scenes outside slide sideways. Quickly though, as if suddenly stalling (and like a feeling of vertigo while perched on the edge of flatness), our eyes and minds recover from this optical illusion. The deception is dispelled, and we are where we were, sitting still, waiting. We check our watches, still moments away from departure.

Moving or not, illusory or not, Ashbery's opening line, after the title "Leaving the Atocha Station" almost instantly thrusts the reader into such a state of accumulating confusion or abstraction, with each word recognized distinctly in isolation, while often attaching in-distinctly to the next one, until finally buckling (or derailing) in its referential attenuations.

The arctic honey blabbed over the report causing darkness ... 
Ashbery's Atocha "arctic," seen alone, suspends itself coldly if clearly before the reader, a wintry white picture instantly projected upon the page (but oddly, one that is nonetheless far removed from a warm Madrid). Immediately, though, "honey" is smeared onto the frozen scene, altering (but not eliminating) the initially crisp arctic air while making the picture now sticky and sweet, with a hint of viscous pigment added, yellow dabbed onto its icy white.

With what follows, though, that still seeable "arctic honey" begins immediately melting in its jarring adjacency to the introduced voices that come out of nowhere and abruptly enter that increasingly slippery scene of the sentence - voices that raucously "blabbed." This noisy interruption instantly opens a dissonantly acoustic dimension onto the previously quiet page, noises that are then linked to some unspecified, but vaguely ominous "report." As a "blabbed ... report" of some real consequence, this "report" appears to have "caus[ed]" the very "darkness" that then brings that first line of language to a screeching halt, to its curtained close. Like a vaguely recollected dream, little is then left behind but an inky blackness overtaking the synesthetic scene.

Nevertheless, Ashbery's opening "darkness" (and perhaps our own) does soon lift and, as if having passed through a lightless tunnel, new sights are instantly, or instamatically, seen through moving windows, on the static page, and onto the poem's already mentioned second line: "pulling us out of there experiencing it." Accelerating, the accumulating pictures then range, quickly, from "fried bats they sell there" to "the menace of your prayer folds ...."; "Other people ... flash." And then, in a kind of blur of unsustainable association, a veritable rush of words pours forth: "comfort of your perfect tar grams nuclear world bank tulip." Like the "flash" of a camera briefly illuminating a darkening scene, each word can be read like a calligraphic stroke upon a moving canvas, offering painterly adjacencies of recognition and resistance, familiarity and estrangement, with the readerly experience now resembling what Ashbery had described of Mitchell's own "antagonisms and sparrings" of picture and paint.

Also, as with Mitchell's "sudden lashings of caked or viscous pigment," we are similarly presented in the Atocha Station with occasional "coordinates of landscape" that briefly, loosely locate us. We are even offered, at times, aspects of what Ashbery suggested of Mitchell's own "legible" lines, like the painting Girolata's "fairly literal impression of the face of a cliff." However, in place of paint, there are in Ashbery's poem written images which then dis-coordinately dissolve - "the table torn from you," Ashbery writes moments later-into what now appear as the poet's own "sudden lashings of caked or viscous" language, perhaps risking that which, toward the end of the poem, Ashbery calls "absolute mush."

The worn stool blazing pigeons from the roof

driving tractor to squash

Leaving the Atocha Station steel

infected bumps the screws

everywhere.... 
At this point in the poem, we might indeed wonder: where are we now? When are we and how? And alas, what's happened to our "experience" of that earlier denoted referencing of "it"? Have we finally moved forward into that it, the poem progressing along those legible lines laid out, its words accumulating into flickering pictures, dissolving one into the other, into the other? Or, as Ashbery describes in a later poem "The Skaters," might it be that what was seen was not seen at all and, fooled again, "The train is still sitting in the station. / You only dreamed it was in motion" (Moorings 221)?

In a 1960 article on Pierre Reverdy, Ashbery writes of the French poet's own movements through a station, in this case, a Paris Metro, of Reverdy's descriptions of a scene's own scenographic dispersions, the sensuality of such a moving sight. And, in reading Ashbery's vivid description of that station, one might reasonably wonder whether a train leaving from Reverdy's Metro might circuitously lead, if followed, all the way to Ashbery's own Atocha station. Ashbery writes:

[Reverdy's] lines drift across the page as overheard human speech drifts across our hearing: fragments of conversation, dismembered advertising slogans and warning signs in the Metro appear and remain preserved in the rock crystal of the poem. And far from banishing poetry to the unconscious, he lets it move freely in and out of the conscious and the unconscious. Since we do not inhabit either world exclusively, the result is moving and lifelike. ... It is a disconcerting kind of poetry, but one feels it must be very close to life as it is actually lived. ("A Note" 21)

Like Reverdy's Metro, Ashbery's Atocha Station similarly drifts across his page, as if across another "moving and lifelike" landscape. And, with all its kaleidoscopic twists and turns along the way, something of the poem's "abstract" experience is not unlike our own multi-dimensional, drifting engagement with the world ... in Girolata, or Atocha, or Paris (or even Florida). As if seen down a street, through a window, thinking, dreaming, and with "a greater, more complete kind of realism," the "rock crystal" of Ashbery's poem indeed would seem to reflect such life as it is "actually lived," "mov[ing] freely in and out of the conscious and the unconscious," while inhabiting "exclusively" neither. In this twilight condition of shifting substance and circumstance, the wheels roll beneath us, setting us in motion to drift forward and back in dissolutions of glimpse and fragment, darkness and sight, "feeling 'living."

Or, once more, with that odd, illusory sensation of false motion sometimes beguilingly felt while waiting in a station, is Ashbery's Atocha "experience" instead something like that of seeing the adjacent train across the way that moves, while we remain unmoving? For the disconcerting dis-locations of it, of Ashbery's poem, are apparently lodged in the language alone, "in the caked or viscous" material of its words, and where, as Ashbery writes further along in the poem, "experiencing it is not to go into" (emphasis mine). For, with the poem before us, we sit entirely still, "continuous and still," while achieving perhaps even something of Mitchell's desired "one word, one image," one at a time, taken, almost timeless in the illusory sense given of a scene from a window sliding by, "pulling us out of there," and the experience of ... it. 
That word as "one word, one image," so terribly tiny there on the page, almost invisible in its simplicity, functions as a radical distillation of the otherwise rapid accumulations of the poem; its shifting excess of scenes filmically flash and flicker into one another, and then another, the it as a "[bit] of landscape and air."

Giorgio Agamben insightfully describes the role of such shifting pronouns as Ashbery's "it," or "us," or "this, " or "them," noting the almost transcendental capacity of such language to locate its own place of utterance, to designate abstractly a site within which to penetrate the otherwise surrounding silence and, like Ashbery's "blabbed" voices, to speak of itself speaking. Agamben writes:

\footnotetext{
The proper meaning of pronouns - as shifters and indicators of utterance - is inseparable from a reference to the instance of discourse. The articulation - the shifting ... does not simply name an unnamed object, but above all the very instance of discourse, its taking place. The place indicated ... is a place of language. Indication is the category in which language refers to its own taking place ... to the very event of language. (25)
}

Ashbery's Atocha correspondingly takes place as just such an "event of language," with its shifting pronouns indicating along the way something of the poem's own utterance, the very instance of it. And, like Mitchell's Girolata and that parallel event of paint, the place thus indicated indistinctly (but, again via Wittgenstein, "exactly [as] we need") is reflecting now, still, recollected like a glint of light from a written window, moving motionless, or off the surface of "a certain cypress tree."

It was Gertrude Stein, that other, earlier American who, like Ashbery and Joan Mitchell, had also lived so long in France, who wrote: "In the beginning was the word. Then they put two words together, then they made a sentence, then they made a paragraph and they forgot the word" (A Stein Reader 263). But now, in Ashbery's Atocha, remembering the word, made to remember the "proper meaning" of the pronominal "it," we might forget the paragraph, forget the sentence, forget the "two words together," with even the time taken to read Ashbery's taxing poem finally returned to us (with interest earned!), seeing ... it ... now, that one word, there, still, "continuous and still," drifting along, alone.

\section{“DYING PULSE TRAINS"}

Finally - and to end on a high note - in the rich and hallucinatory lexicon of contemporary astrophysics (of which I know next to nothing), I was recently delighted to discover, in a newspaper article about black holes, the image of a train, one that might even be thought of as leaving a station [Figure 4]. The scientists call it, of all things, a "dying pulse train." This particularly celestial train is, they explain, constituted by the collapsing matter of a dying star that leads, in its dissolutions, all the way to what is then movingly described as the "event horizon," spiraling inward to the very lip of an unseeable, but indicated "black hole." Dr. Michael Garcia is quoted in the article as stating, "It's a bit odd to say 


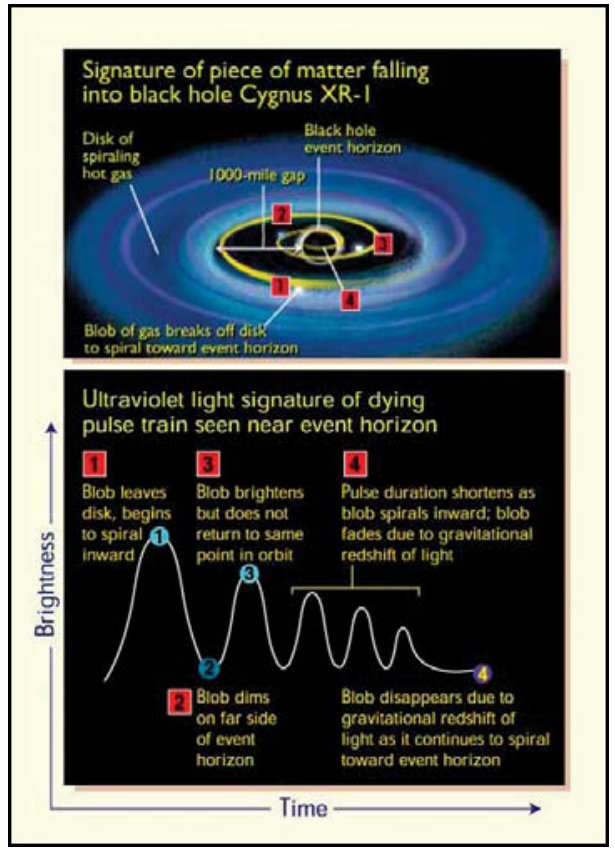

Figure 4. Source: Ann Field (STScI).

we've discovered something by seeing almost nothing but, in essence, this is what we have done" (Wilford).

Now, returned to earth, might Ashbery's Atocha train and the "dying pulse" of his poem be similarly imagined as leading us to the horizon of his event of language where we also "[discover] something by seeing almost nothing"? Experienced there, as if arising in part by the false motion of an adjacent train's movement, is a feeling of leaving, of feeling leaving, of "feeling 'living" the Atocha Station, as it tunnels toward the lip of its own indicated black hole, this spiraling jetty of disappearing matter (that suddenly matters so much). "Pulling us out of there experiencing it," the light reflects off windowed words and sliding scenes, "moving and lifelike," its dense matter collapsing, its particles proliferating, "bits of landscape and air," into a narrowing space of singularity, no light escaping, no larger than that, no larger than "it."

Notes

1. An earlier version of this essay was delivered at the "John Ashbery in Paris" conference, March 2010. In addition to my presentation, I was asked to do a poetry installation in conjunction with the conference and Ashbery's own poetry. Selections from this installation can be seen at my website: $<$ http://www.unf.edu/ clunberr/Lunberry/Installations.html>.

2. Stein's complete quote is as follows: "America is my country and Paris is my home town and it is as it has come to be. After all anybody is as their land and air is. Anybody is as the sky is low or high, the air heavy or clean and anybody is as there is wind or no wind there. It is that which makes 
them and the arts they make and the work they do and the way they eat and the way they drink and the way they learn and everything" ("An American and France," n.p.).

3. I suspect that Ashbery's "haunted" feeling about this early comment regarding abstraction suggests less a renunciation of it than the belief that the statement is almost too helpful, too revealing of the poet's intentions. In the future, Ashbery generally proves far less forthcoming about his poetic purposes, leaving his intentions much more open-ended and undefined, so that the reader is left alone to fix a frame onto the crafted opacities of the poem.

\section{Works Cited}

Agamben, Giorgio. Language and Death: The Place of Negativity. Trans. Karen E. Pinkus and Michael Hardt. Minneapolis: U of Minnesota P, 1991. Print.

Ashbery, John. "Introduction." The Collected Poems of Frank O'Hara. Ed. Donald Allen. Los Angeles: $\mathrm{U}$ of California P, 1993. vii-xii. Print.

—. The Moorings of Starting Out: The First Five Books of Poetry. New York: Harper Collins, 1997. Print.

- Reported Sightings: Art Chronicles, 1957-1987. Ed. David Bergman. New York: Alfred A. Knopf, 1989. Print.

. "A Note on Pierre Reverdy." Selected Prose. Ed. Eugene Richie. Ann Arbor: U of Michigan P, 2004. 19-24. Print.

- The Tennis Court Oath. Middletown, CT: Wesleyan UP, 1962. Print.

Bernstock, Judith E. Joan Mitchell. New York: Hudson Hills, 1988. Print.

Bloom, Harold. "The Charity of the Hard Moments." John Ashbery. Ed. Harold Bloom. New York: Chelsea House, 1985. 44-72. Print.

Feldman, Morton. Give my Regards to Eighth Street: Collected Writings of Morton Feldman. Ed. B.H. Friedman. Cambridge, MA: Exact Change, 2000. Print.

Lehman, David. The Last Avant-Garde: The Making of the New York School of Poets. New York: Doubleday, 1998. Print.

Stein, Gertrude. “An American and France.”1936. TS. American Literature Collection, Yale University Beinecke Library, New Haven, CT.

- A Stein Reader. Ed. Ulla E. Dydo. Evanston, IL: Northwestern UP, 1993. Print.

Stiles, Kristine and Peter Selz, eds. Theories and Documents of Contemporary Art: A Sourcebook of Artists' Writings. Berkeley: U of California P, 1996. Print.

Wilford, John Noble. "Scientists Find Footprints for Matter, Before it Disappears into Black Holes." New York Times 11 Jan. 2001: D2. Print.

Wittgenstein, Ludwig. Philosophical Investigations. Trans. G.E.M. Anscombe. Oxford, UK: Blackwell, 2001. Print. 